消化器進行癌に対するレーザー手術の応用とその効果

\title{
Clinical application and its appraisal of the laser surgery to advanced carcinoma of the digestive organs
}

今野哲朗、佐野文男、白戸博士、能登哲光、樟本賢首、佐藤直樹 西田 修、秦 温信、中西昌美、内野純一

Tetsuro Konno, Fumio Sano, Hiroshi Shiroto, Hiromitsu Noto, Kenju Kusumoto, Naoki Sato, Osamu Nishida, Yoshinobu Hata, Masami Nakanishi, Junichi Uchino 北海道大学医学部第 1 外科

First Department of Surgery, Hokkaido University, School of Medicine

In the advanced carcinoma of the digestive organs, the local recurrence is a major problem in surgery. We have applied a laser irradiation to the area after lymph node dissection in the surgery for the carcinoma of the GI tract and to the raw surface of the liver after hepatic resection. Experimental study demonstrated that the laser surgery have an advantage to prevent the local recurrence. Of 133 patient undergoing the laser surgery, ten patients underwent the laser irradiation and none of these developed the local recurrence so far after 4 years in the longest-term follow up. 47 patients underwent hepatic resection using a laser knife and proved to be a good prognosis. Postoperative prognosis although enough estimation çan not be made is preliminarily favolable as a whole.

はじめに

レーザーメスは一般外科領域における悪性腫境, 特に消化器癌の手術に利用され，その有用性が報 告されているが，いまだレーザー光の特性を十分 発揮されるような利用法は確立されていない。1)233)

そてで今回は, 当科で行なっている消化器進行 稳に対するレーザー手術の適応について述べると ともに，レーザー手術の局所再発抑制効果につい $\tau$, 奏験的に検討した結果之、消化器進行瘦に対
する踤床応用の成績について報告する。

1. レーザー手術の適応

消化器進行癌に対するレーザー手術の適応にあ たって, まず消化器進行癌の問題点について述べ る。進行磘で問題となってくるのは, 第 1 亿再発 である(図 1 )。当科で経験した消化管悪性腫鹤 の手術成績をみると, 大腸・直腸癌の治瘾切除例 の $38 \%$ 再発をみている。再発に関する园子を 
みるよ，その大半が局所掞よびリンパ系の再発に よるものである。従って従来の腫湯切除部位の処 理およびリンパ郭清の方法では，治療成績の向上 には限界がある。第 2 亿進行糔では術中操作に上 る腫瘍細胞の散布が問題亡なる。第 3 にさらに進 行すると腹膜, 横隔膜への直接浸潤や播種が問題 となる。

このような観点から，最近われわれは消化管覀 性腫瘍, 特に進行癌に対しては, 腫瘍切除部位, および従来通りの定形的なリンパ郭清を行なった 後の郭清術野にレーザー照射を行ない、また腹膜, 横隔膜への直接浸潤や播種栄へは病香の切除後レ ーザ一照射を行なってきた（図１）。

\section{1. 再 発}

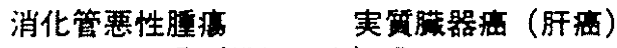 \\ (根治手術)}

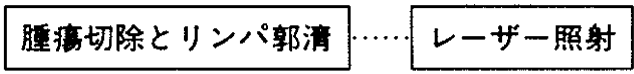

† (再 発)

\begin{tabular}{|l|l|}
\hline 局 & 所 \\
リンハ系
\end{tabular}

\section{2. 直接漫润，璄膜播種巣}

レーザー照射

3. 術中操作による腫潐細胞の散布

レーザー照射

図 1. 消化器進行癌の問題点

肝など実質臟器斋では断端再発が問題となる。 そこでわれわれは胿癌の手術に際し，レ一ザーメ スで切離し，切離面に対しレーザー照射を行なっ てきた。つまり消化器進行癌に対するレーザー手 術の適応の主眼点は，初回手術において根治性を 高め，局所再発を抑制するととにある。

\section{2. 実験成績}

レーザー手術の局所再発抑制効果をみるため， D A B 誘発実験肝蹦による，担癌ラットを用い， 鋼刃メスおよびレーザーメスを用いて腫瘍切除を 行ない, 腫瘍再発之生存日数について比較検討し た。図 2 の上段は鋼刃メスおよびレーザーメスに

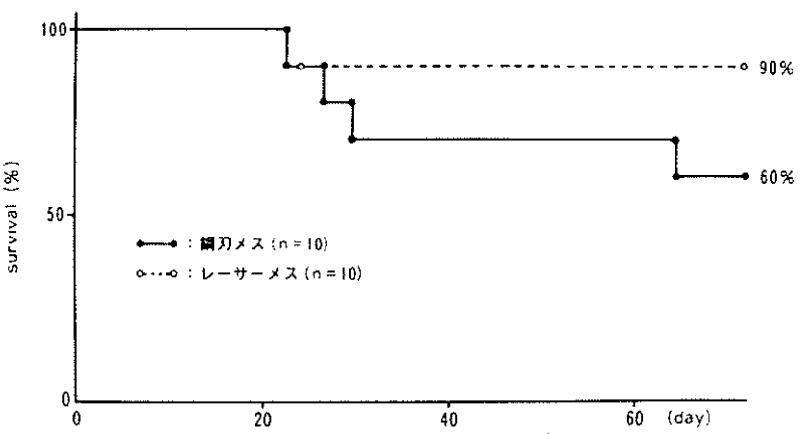

術野堙斯細胞散布例の生存事

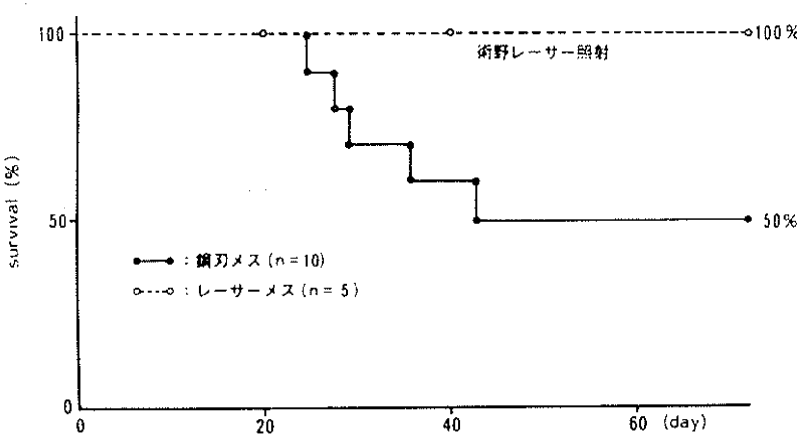

図 2. 担癌ラットにおける腫㾕切除後の生存率

よる腫場切除後の生存率を示すが, 鋼刃メス群 10 例中 4例が腫瘍切除後 23 日から 64 日までに再 発死亡したのに対し，レーザーメス群では 10 例 中 I 例が腫湯切除後 23 日に再発死亡したが, そ の後 3 力月目までに再発はみられていない。

下段は腫瘍細胞を散布しながら腫瘍切除を行な い,さらにレーザーメス群では腫塐切除部位に広 範にレーザー照射を行なった場合の生存率を示す が，鋼为メ又群では 10 例中 5 例が腫㵧切除後 23 日から43日までに再発死亡したのに対し、レー ザーメス群では 3 力月目まで再発死亡はみていな wo

この実験結果よりレーザー手術群に腫湯再発の 抑制効果が認められるととから, 消化器進行癌に 対するレーザー手術の有用性が示されていると考 える。

3. 臨床成績

1979 年以来レーザーメスを消化器癌の手術 
に導入し1984年7月までに 1333 例にレーザ

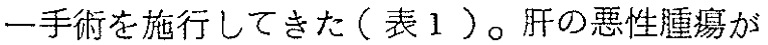
84 例 $(63 \%)$, 消化管のそれは 33 例 ( 25 \%)となっている。梁達度 P M以上の消化管や， 直径 $2 \mathrm{~cm}$ 以上の原発性肝癌など進行癌は１０ｌ例 を数える。そのうち根治性を高める目的で腫癔切 除部位およびリンパ㰻清後の郭清術野にレーザー照射した症例は消化管で 10 例，内訳は食道 2 例， 胃 1例，大腸・直腸 7 例である。罗長生存は4 年 上再発屯なく全例生存中である。胆, 膵は高度進 行癌が多く，根治切除をめざしたレーザー手術例 はなかった。用では，試験切除を除き根治性をめ ざしたレーザー手術施行例は４７例であった（表 1) 0

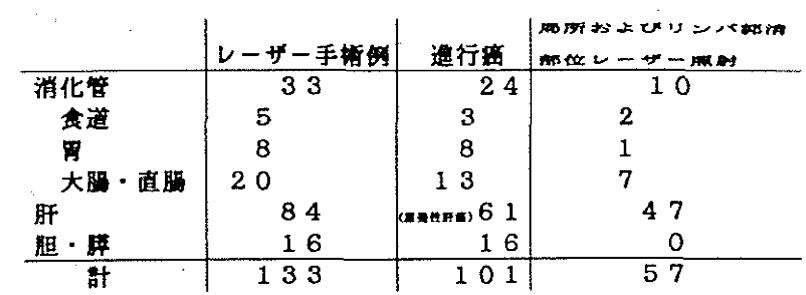

表 1. 消化器癌に対するレーザー手術症例

肝癌のレーザー手術成績を $\mathrm{Kaplan}$-Meir 法 抢よびCox-Mantel デストを用いて検討する 之，1区域および2区域切除とむレーザ一手術群 に良好な生存率が得られた。しかし2区域切除で はレーザーメス群が 3 例と少ないため問題が残り， 三区域切除においては雨者に生存率の差はみられ なかった（図3）。

そこで 1 区域切除および 1 区域以下切除のレー ザ一手術群に良好な生存率が得られた理由を調べ るため，雨者の背舅因子を比較検討した（表2）。

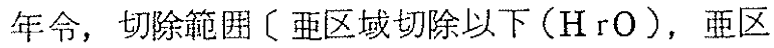

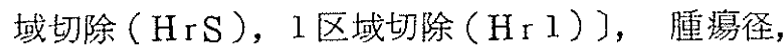
被膜形成の有無，進展度，硬变の有無といった因 子では雨者間に决定的な差はない。しかし胠切離 面から腫㾤までの最短距離が $10 \mathrm{~mm}$ 以内のもの, すなわち TW（十）例が非レーザ一群では全例に， レーザー群では 10 例中 6 例のみに認めた。すな わち根治性に最も関与するとされるTW因子の差
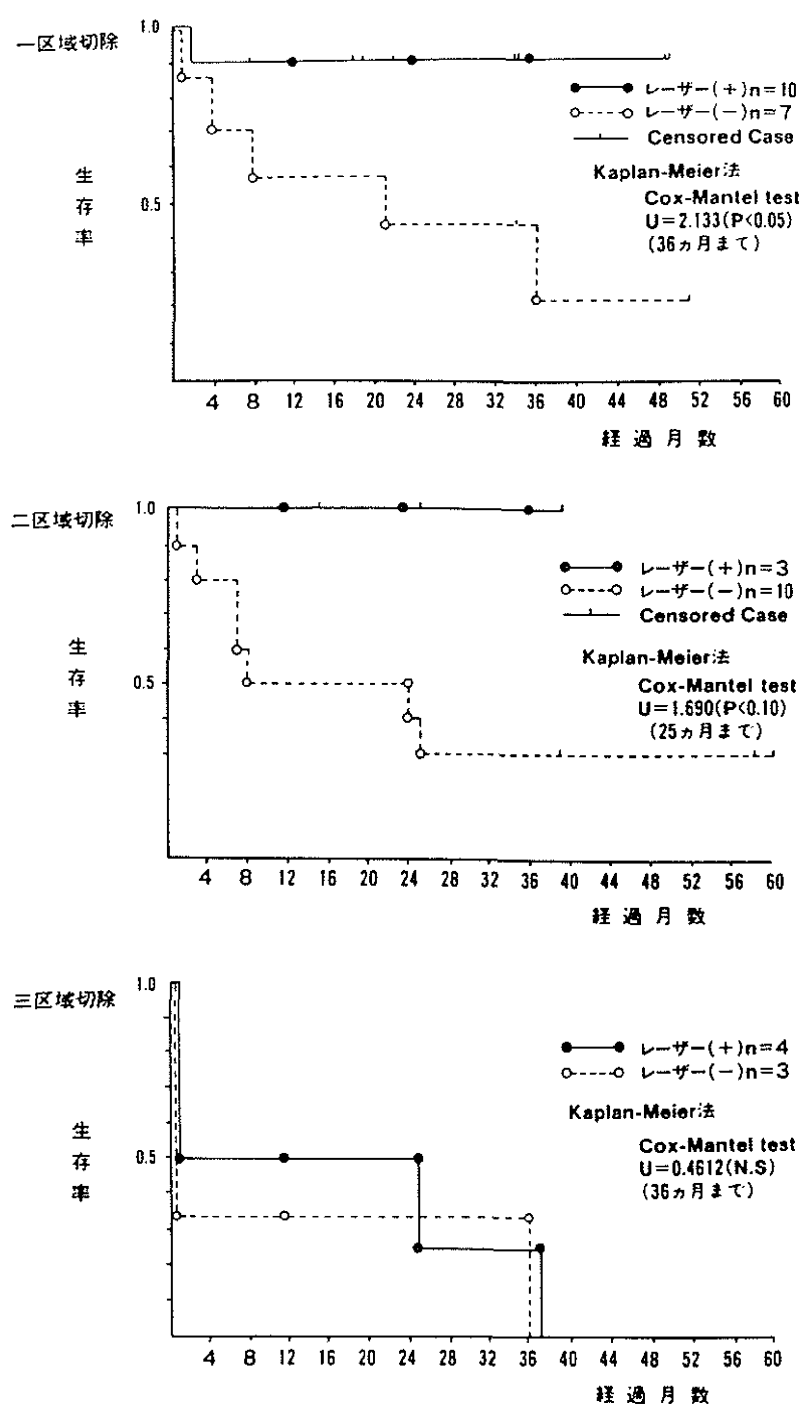

図 3. 肝癌のレーザー手術成續

が生存率の差となって現われたすのと思われる。 レーザー手術では止血的切開が可能なため24)腫舅 から距離をはなしての切除が可能となる。

\begin{tabular}{|c|c|c|}
\hline & 非レーザー $n=7$ & レーザー $n=10$ \\
\hline 龄 & $58.9 \pm 3.9$ & $54.0 \pm 3.0$ \\
\hline 式 $\begin{array}{c}\mathrm{HrO} \\
\mathrm{HrS} \\
\mathrm{Hr} 1\end{array}$ & $\begin{array}{l}3(43 \%) \\
3(43 \%) \\
1(14 \%)\end{array}$ & $\begin{array}{l}3(30 \%) \\
5(50 \%) \\
2(20 \%)\end{array}$ \\
\hline 肝切碓面 Tw & $7(100 \%)$ & $6(60 \%)$ \\
\hline 腈徍 $(\mathrm{cm})$ & $5.1 \pm 1.9 \times 4.1 \pm 1.0$ & $3.6 \pm 0.9 \times 3.2 \pm 0.6$ \\
\hline 被腃形成 FC: & $6(86 \%)$ & $8(80 \%)$ \\
\hline 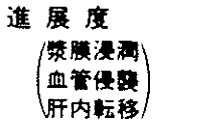 & $3(43 \%)$ & $2(20 \%)$ \\
\hline 硬变 Z到 & $6(86 \%)$ & $7(70 \%)$ \\
\hline
\end{tabular}

表2.1区域またはそれ以下の切除例の背景因子 一非レーザー群とレーザー群の比較— 


\section{4. レーザー手術の臨床応用}

レーザーメスは食道，胃，大腸など消化管悪性 腫瑒に対しては, 表 3 に示したでとく, 鋼刃メス 之同様化切開，切離，仙骨前面や側方郭清および リンパ郭清の際に利用出来る。進行噯では, 特に リンパ郭清後の郭清術野，腫瘍切除部位および腹 膜浸潤栄へのレーザー照射が適応となる年5)

肝なざ実質臟器に対しては，切離面および切離 面の残存腫湯に詨する照射・焼灼，腹膜や横隔膜 などへの直接浸潤や転移单への照射が適応となる (表 3 )。

\section{消化管悪性量理}

\section{悠血的切開・切部

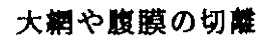 仙前面や僛方邲清 系茫的リンパ暗消 ○リンパ剠消部位 O臣姑切险部位

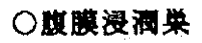 への胃射}

\section{O印進行藕に迹}

表 3，消化器癌に対するレーザー手術の応用

次に個々の消化器癌に対するレーザー手術の臨 床危用例を示す。

食道滛の手術に際しては, 従来通り食道全摘し, ついで後縦隔のリンパ郭清後, 郭清術野の散布演 細胞や遗残癌細胞を対象に広範なレーザー照射を

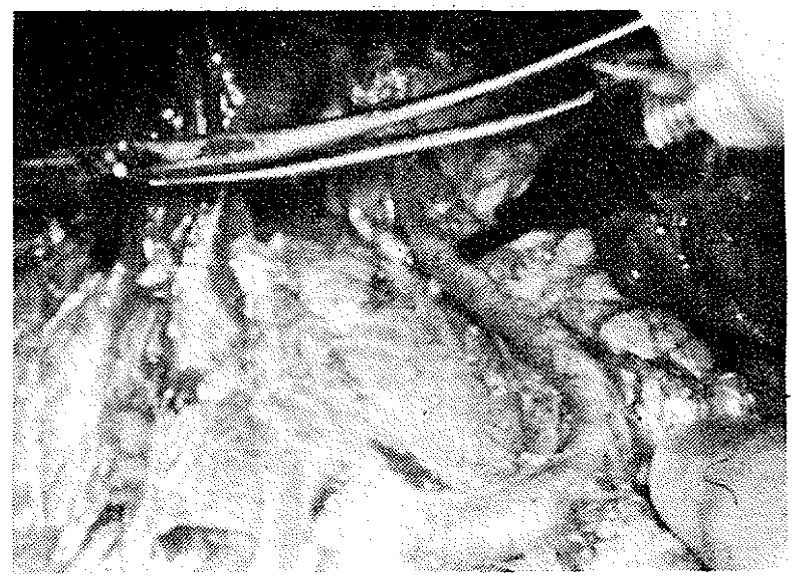

図 4. 食道全摘後, 後縱隔へのレーザー照射
行なう。図4の症例は胸骨縦切開にて食道全摘を 行なったが，術後 1 年 2 力月たった現在，再発む なく生存中である。

胃泊手術では，胃切除後，従来通り，定形的な 系統的リンパ郭清を行なった後, 腹腔動脈周辺部

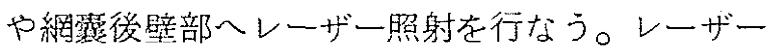
照射は散布癌細胞の烓灼やリンパ管の㠜固・閉鎖 に働らき，転移や再発の予防に有効之考えられる。 結腸や直腸澏に対しては, 腫瘍切除部位の後腹 膜, リンパ郭清後の郭清術野, 特に直腸切除の際 の仙骨前面や側方郭清後の郭清術野や直腸之接す る小骨盤前壁へのレーザー照射が主たる適応とな る(図 5 )。

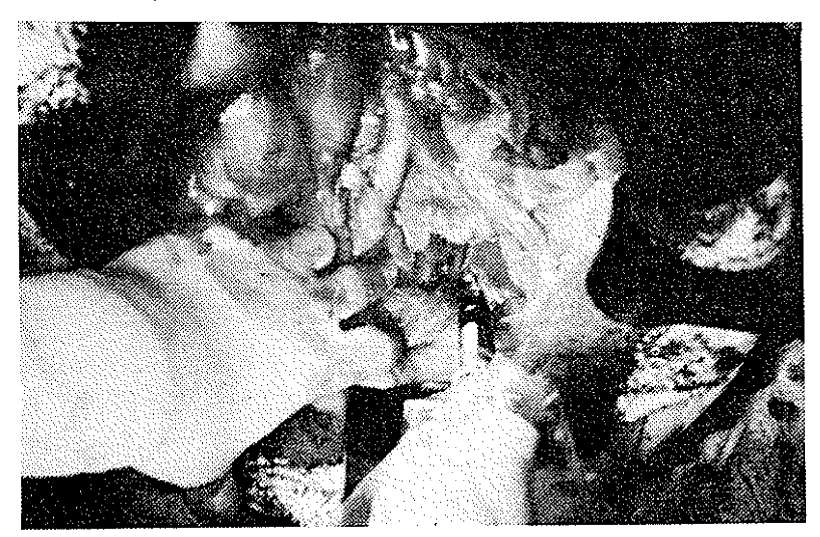

図 5. 仙骨前面へのレーザー照射

実質臟器である肝癌に対しては，肝切離面に広 範な照射を行なっている。Na-YAGレーザーを用

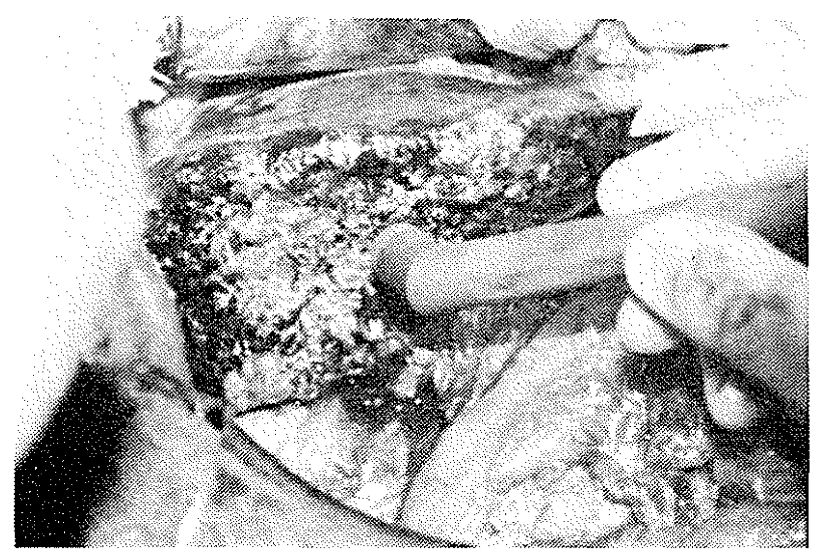

図 6. $\mathrm{CO}_{2}$ defocused beams に上る肝切離面照射 


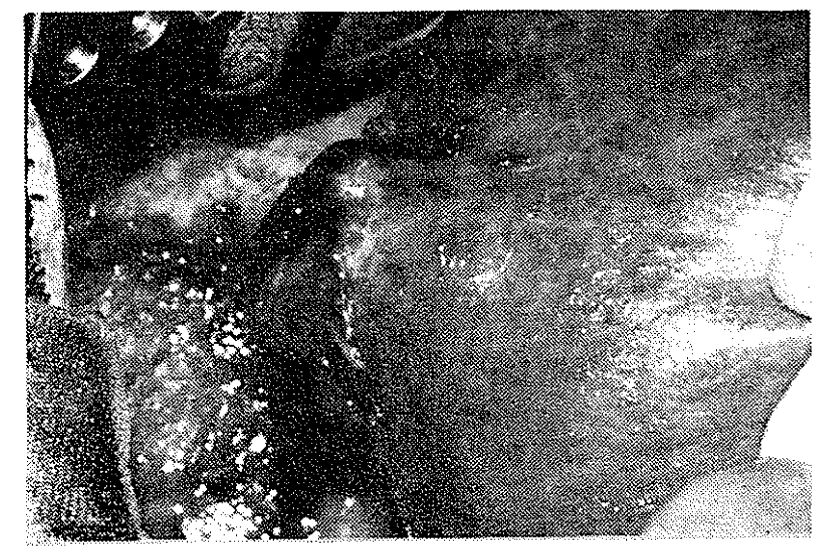

図 7. 肝瘦の横隔膜への直接浚潤を示す

\section{いて肝切除在行ない,}

$\mathrm{Nd}-\mathrm{YAG}$ Coag-

ulatorまなは $\mathrm{CO}_{2}$ defocused beam にて 肝切離面を照射する（図6）。肝切離面に対する

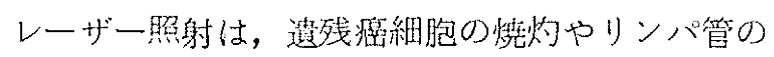
㠜固閉塞に有効で肝癌細胞の移行を防止し再発を 抑制できる可能性がある。

横隔膜, 腹膜などへの直接浸潤や播種をおこし た症例に対しては（図 7), 病栄切除後, 切除部 位をレーザー照射している(図8)。

\section{おわりに}

消化器㺕に対するレーザー手術においては，い まだレーザー光の特徵を十分に発揮された利用法 は確立されておらず，試行錯愦の状態である。レ 一ザー手術の適莈は，従来の鋼刃メスで行なって いた操作部位へ，かわってレーザーメスを導入す る方法と、レーザー光の特性を生かした特殊な利 用法の二通りある。後者の適応は可成り限定され たものにならざるを得ないが，広範なレーザー照 射が可能である特性を生かして，われわれは消化

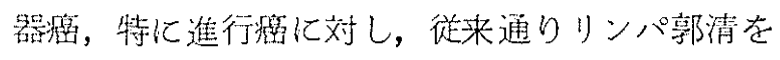
行なった後，郭清術野にレーザー照射を行なって きた。消化器癌の治虑切除例の成績をみても局所 およびリンパ系の再発が多いととから，今後治療 成績を向上させるには，従来のリンハ㗥清を徹底 するとともに，郭清術野にレーサー照射を行なう ととは意義があると考えられる。消化器進行癌に

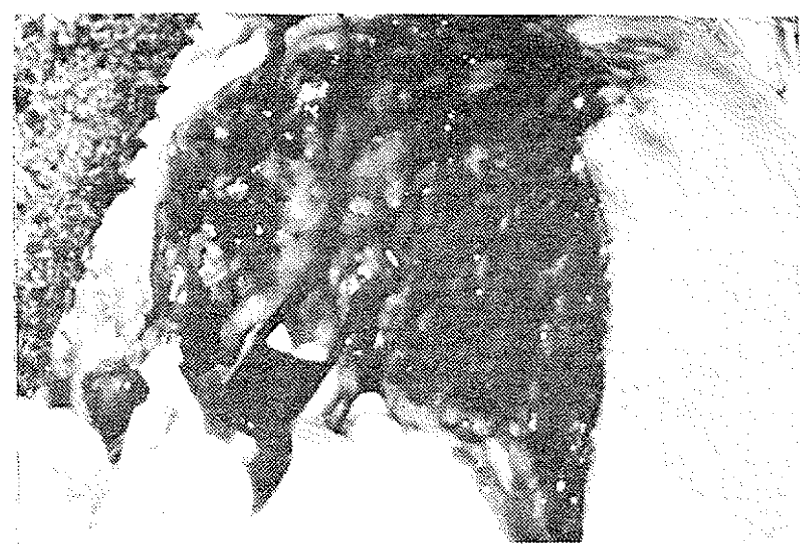

図 8. 左の症例で, 横隔膜浸潤部位の切除後, 切 除部位および肝切離面へのレーザー照射を示す

対するレーザー手術の適応を，初回手術において 根治性を高文，局所再発の抑制に主眼点をおいて 進めており, 近接予後の面からは有効であったと 考えられる。

\section{文献}

1）佐野文男, 葛西洋一, 中島保明, 他: 炭酸力゙ スレーザーメスの一般外科的応用，医科器械 学, $50: 33,1980$

2）葛西洋一，佐野文男：レーザーメス，一般外 科への応用, 臨床外科, $37(4): 467,1982$

3）佐野文男, 葛西洋一, 中島保明, 他: 消化器 硗に括けるレーザー手術の効用とその限界, 日本レーザー医学会誌，3：127, 1982

4) 佐野文男, 中西昌美, 葛西洋一, 他: 腹部手 術に㧍けるレーザーの応用, 手術, 37:299, 1983

5）葛西洋一, 今野哲朗, 中西昌美, 他: ME機 器の消化器外科領域への応用, メデカルコン パニオン, 4(8): 10007,19984

6）葛西洋一，佐野文雄：レーザー治療：レーザ 一之朋缄外科, 医学のあゆみ, $124: 538$, $\begin{array}{llll}1 & 9 & 8 & 3\end{array}$ 